FACTA UNIVERSITATIS

Series: Physical Education and Sport, Vol. 16, No 2, 2018, pp. 271 - 280

https://doi.org/10.22190/FUPES180525024L

Research article

\title{
RELATIONSHIPS BETWEEN ARM SPAN AND \\ THE MECHANICS OF THE ONE-REPETITION MAXIMUM TRADITIONAL AND CLOSE-GRIP BENCH PRESS
}

\author{
UDC 796.12 \\ 796.12 .1
}

\author{
Robert G. Lockie', Samuel J. Callaghan², \\ Ashley J. Orjalo', Matthew R. Moreno ${ }^{1}$ \\ ${ }^{1}$ California State University, Fullerton, USA \\ ${ }^{2}$ Kingston University, London, UK
}

\begin{abstract}
The traditional bench press (TBP), performed with a grip width that maximizes strength, is a popular exercise for developing the upper-body. The close-grip bench press $(C G B P)$ is a variation of the TBP often used to emphasize the triceps brachii over prime movers such as the pectoralis major. An individual's arm span (AS; distance between the middle fingers of each hand while the arms are outstretched) could affect the mechanics of each exercise, which may be exacerbated by the change in grip. This study investigated relationships between $A S$ and TBP and CGBP mechanics in resistance-trained men. Twenty-one participants completed a one-repetition maximum (1RM) TBP and CGBP. The TBP was performed with the preferred grip (measured relative to biacromial distance [BAD]), and the CGBP with a grip width of 95\% BAD. A linear position transducer measured: lift distance; peak and mean power, velocity, and force; the distance and time when peak power occurred; and work. Pearson's correlations $(r ; p<0.05)$ computed relationships between AS and TBP and CGBP mechanics. There were significant positive relationships between AS and TBP lift distance and work $(r=0.46$ and 0.51 , respectively). For the CGBP, there was a significant positive relationship between $A S$ and work $(r=0.48)$. There were no other significant correlations between AS and lift mechanics. Resistance-trained men with a longer AS may move the bar further and perform more work in the IRM TBP and CGBP. This could influence how coaches measure training volume and intensity for individuals with different $A S$.
\end{abstract}

Key words: arm length, lift distance, linear position transducer, upper-body strength.

Received May 25, 2018 / Accepted September 17, 2018

Corresponding author: Robert George Lockie

California State University Fullerton, 800 N State College Blvd, Fullerton, CA 92831, USA

Phone: +1 657-278-4971•E-mail: rlockie@fullerton.edu 


\section{INTRODUCTION}

The bench press is one of the foundation exercises used to develop upper-body pushing strength (Algra, 1982; Gomo \& Van Den Tillaar, 2016; Lehman, 2005). As described in the literature (Lockie et al., 2017a; Lockie et al., 2017b), the bench press is customarily performed from a supine position on a bench, with a barbell held above the chest with the arms extended at the elbows. From this position, the bar is lowered to the chest until contact is made just above the xiphoid process, before the bar is forcefully pressed upwards until the elbows are extended once more. The grip width adopted in the traditional bench press (TBP) is usually a preferred width where the individual feels they can lift the greatest load, which can be termed the individual's 'strongest position' (Young et al., 2015). This typically involves a hand position that is wider than the shoulders (165-200\% of biacromial distance [BAD]), such that the elbows will form an approximate $90^{\circ}$ angle at the bottom position when the bar contacts the chest (Clemons \& Aaron, 1997; Lockie et al., 2017a; Lockie et al., 2017b; Wagner et al., 1992).

The close-grip bench press (CGBP) is a variation of the TBP which is often used to emphasize the triceps over prime movers such as the pectoralis major (Barnett, Kippers, \& Turner, 1995; Lehman, 2005; Lockie \& Moreno, 2017). There is less shoulder abduction during this exercise which keeps the hands closer to the torso (Gomo \& Van Den Tillaar, 2016), and this exercise can feature grip widths of 95-100\% of BAD (Clemons \& Aaron, 1997; Lehman, 2005; Lockie et al., 2017a; Lockie et al., 2017b; Lockie \& Moreno, 2017; Wagner et al., 1992). In addition to changing the muscle activation patterns, Lockie et al. (2017a) suggested that the CGBP could be more specific to actions required in different sporting activities, including: fending in rugby union or league (Wheeler \& Sayers, 2009; Wheeler \& Sayers, 2011); blocking in American football (Stokes, Luiselli, Reed, \& Fleming, 2010); and performing a chest pass in basketball and netball (Cronin \& Owen, 2004; Delextrat \& Cohen, 2009). To this end, Lockie et al. (2017a) compared the mechanics of the CGBP to that of the TBP in resistance-trained men and women when measured by a linear position transducer. Lockie et al. (2017a) found that a lighter load was lifted in the CGBP compared to the TBP $(83.03 \pm 24.67$ kilograms $[\mathrm{kg}]$ vs. $87.65 \pm 27.23 \mathrm{~kg})$, which led to a lower mean force during the lift $(820.03 \pm 240.36$ newtons $[\mathrm{N}]$ vs. $861.74 \pm 269.48 \mathrm{~N})$. However, the CGBP led to the generation of greater peak power $(376.48 \pm 149.66$ watts [w] vs. $313.18 \pm 105.94$ w) and velocity $\left(0.43 \pm 0.07\right.$ meters per second $\left[\mathrm{m}^{\bullet} \mathrm{s}^{-1}\right]$ vs. $\left.0.35 \pm 0.06 \mathrm{~m} \bullet \mathrm{s}^{-1}\right)$, which Lockie et al. (2017a) suggested could be beneficial for athletic activities where explosive upper-body actions were required.

Interestingly, despite an arm position that involved less shoulder abduction to position the hands closer to the torso, Lockie et al. (2017a) also found there was no significant difference in the lift distance for the CGBP and TBP $(0.43 \pm 0.05$ meters [m] vs. $0.41 \pm 0.04 \mathrm{~m})$, and this was also true for the work performed in each lift $(239.87 \pm 128.94$ joules $[\mathrm{J}]$ vs. $265.64 \pm 150.31 \mathrm{~J})$. This was despite previous research illustrating that performing the bench press with different grip widths led to changes in the distance of the bar from the shoulder during the ascent phase of the lift (Wagner et al., 1992). Additionally, Wagner et al. (1992) found no significant relationships between anthropometrical measurements such as arm or forearm length (correlation coefficient [r] $=-0.24$ to -0.34$)$ with the load lifted during the bench press across a range of grip widths $(90-270 \%$ BAD) in strength-trained men. However, Wagner et al. (1992) did not measure important mechanical variables from the bench press, including peak and mean power, velocity, and force (Lockie et al., 2017a; Lockie et al., 2017b). What Wagner et al. (1992) also did not measure, and could affect the lift mechanics in the CGBP and TBP, is arm span (AS). AS is measured as the distance between the middle fingers of each hand while the arms are outstretched (Dawes, Marshall, \& Spiteri, 2016; Dumith et al., 2010; Teramoto et al., 2018), and this metric incorporates the length of both arms. Anecdotally, it may be assumed that AS could affect the lifting mechanics of bench press exercises, as longer arms might result in greater bar displacement. This is notable, as limb length has been found to affect the mechanics of other resistance exercises. Lockie et al. (in 
press) found that a longer leg length correlated with greater work performed in the conventional deadlift (Spearman's correlation coefficient $[\rho]=0.72)$, and with greater lift distance $(\rho=0.57)$ and work $(\rho=0.68)$ in the high-handle hexagonal bar deadlift when performed by resistancetrained men. For the conventional deadlift, a longer arm length also related to greater work performed $(\rho=0.58)$. Lockie et al. (in press) noted that this was important information for strength and conditioning coaches, as there could be discrepancies in the actual work performed during a resistance training session between individuals with different limb lengths who have been programmed the same exercises and load. Individuals with longer arms may perform more work during the bench press, in addition to experiencing changes in other lifting mechanics, which could be exacerbated in the CGBP due to the different grip.

Therefore, this study investigated the relationships between AS and the mechanics of the onerepetition maximum (1RM) TBP and CGBP. The TBP was performed with the preferred grip width for the individual, while the CGBP was performed with a grip width of 95\% BAD (Lockie et al., 2017a; Lockie et al., 2017b). Resistance-trained men performed the two lifts, and both the TBP and CGBP were measured with a linear position transducer. The data that was recorded included: lift distance (i.e. bar displacement); peak and mean power, velocity, and force; the timing and location of peak power; and work. The use of a linear position transducer to measure the mechanics for the TBP and CGBP was conducted to ensure the data would have practical value to the strength and conditioning coach (Drinkwater et al., 2007; Harris et al., 2010; Lockie et al., 2017a; Lockie et al., 2018; Lockie et al., in press). It was hypothesized that a longer AS would relate to greater lift distance and work in both the TBP and CGBP. A longer AS would also relate to the other mechanical variables of power, velocity, and force, due to the changes in bar displacement. Given the importance of measuring training load to optimize physical adaptations and avoid overtraining in athletic populations (Fry \& Kraemer, 1997; Marston, Peiffer, Newton, \& Scott, 2017; McBride et al., 2009; Smilios et al., 2013), it is important to note the actual work done during resistance training and whether this is affected by anthropometry (Lockie et al., in press).

\section{METHODS}

\section{Participants}

Twenty-one resistance-trained men (age $=23.86 \pm 4.42$ years; height $=1.76 \pm 0.06 \mathrm{~m}$; body mass $=81.80 \pm 15.82 \mathrm{~kg}$ ) volunteered to participate in this study. Participants were recruited from the student population at the university. All participants were required: to be currently resistance training ( $\geq$ three hours per week) with a focus on either hypertrophy or maximal strength; have a resistance training history ( $\geq$ two times per week) of at least two years; be experienced with the TBP and CGBP; and free from any musculoskeletal disorders that would influence their ability to complete the study. G*Power software (v3.1.9.2, Universität Kiel, Germany) was used post hoc to confirm that the sample size of 21 was sufficient for a correlation, point biserial model, and ensured the data could be interpreted with a moderate effect level of 0.55 (Hopkins, 2004), and a power level of 0.82 when significance was set at 0.05 (Faul, Erdfelder, Lang, \& Buchner, 2007). The institutional ethics committee approved the procedures used in this study. All participants received a clear explanation of the study, including the risks and benefits of participation, and written informed consent was obtained prior to testing. 


\section{Procedures}

Participants completed one testing session, and all assessments were conducted in the teaching gym at the university. Prior to data collection, the participant's age, height, body mass, BAD, and AS were recorded. Height was measured barefoot using a portable stadiometer (Seca, Hamburg, Germany), body mass was recorded by electronic digital scales (Tanita Corporation, Tokyo, Japan), and the anthropometric measurements were conducted with a handheld tape measure (Lufkin, Sparks, Maryland). BAD was measured as the distance between the acromion processes for each shoulder (Lockie et al., 2017a). AS was measured as the distance between the middle fingers of each hand while the arms are outstretched (Dawes et al., 2016; Dumith et al., 2010; Teramoto et al., 2018). The procedures used for the 1 RM TBP and CGBP testing have been described in detail in the literature (Lockie et al., 2017a; Lockie et al., 2017b); the reader is directed to these studies.

As per previous research (Lockie et al., 2017a; Lockie et al., 2017b), data was recorded during each TBP and CGBP 1RM attempt by a GymAware Powertool linear position transducer (Kinetic Performance Technology, Canberra, Australia). The external end of the cable was attached on the inside of the barbell (i.e. inside the plates, and on the outer part of the grip section of the bar) for both the TBP and CGBP, with the unit positioned on top of a weight plate placed on the floor directly underneath the bar. Data for bar displacement and velocity were recorded at 50 Hertz, with the barbell load was entered into the software to calculate power and force for every 3 millimeters of bar movement (Drinkwater, Moore, \& Bird, 2012). Data for the 1RM was collected and stored on an iPad handheld device (Apple Inc., Cupertino, California), before being uploaded to an online database and exported into Microsoft Excel (Microsoft CorporationTM, Redmond, Washington, USA). The variables analyzed in this study included:

- Lift distance (i.e. displacement of the bar from lift initiation to lockout, measured in $\mathrm{m}$ );

- Concentric peak and mean power (w);

- Actual (measured in $\mathrm{m}$ and s, respectively) and relative (both measured as a percentage; \%) distance and time when peak power occurred during the lift;

- Peak and mean velocity $(\mathrm{m} \bullet \mathrm{s}-1)$;

- Peak and mean force $(\mathrm{N})$; and

- Work (J).

\section{Statistical Analysis}

All statistics were computed using the Statistics Package for Social Sciences Version 24.0 (IBM, Armonk, United States of America). Descriptive statistics (mean \pm standard deviation [SD]; 95\% confidence intervals [CI]) were used to provide the profile for each measured parameter, and stem-and-leaf plots confirmed a normal distribution in data for each variable. Pearson's two-tailed correlation analysis determined relationships between AS with the mechanical variables for the TBP and CGBP. An alpha level of $\mathrm{p}<0.05$ was required for significance. The correlation strength was designated as: an $\mathrm{r}$ between 0 to 0.3 , or 0 to -0.3 , was considered small; 0.31 to 0.49 , or -0.31 to -0.49 , moderate; 0.5 to 0.69 , or -0.5 to -0.69 , large; 0.7 to 0.89 , or -0.7 to -0.89 , very large; and 0.9 to 1 , or -0.9 to -1 , near perfect for relationship prediction (Hopkins, 2002).

\section{RESULTS}

The mean AS for the participants in this study was $1.81 \pm 0.08 \mathrm{~m}$. Descriptive data for the TBP and CGBP is shown in Table 1, while the correlation data between AS and the TBP and CGBP variables is shown in Table 2. For the TBP, there were significant positive relationships between lift distance (moderate effect) and work (large effect). With regards to the CGBP, there was a significant positive relationship with work, which had a moderate effect. There were no significant 
relationships between AS and peak and mean power, velocity, and force, or the distance and time where peak power occurred.

Table 1 Descriptive statistics (mean \pm SD; 95\% CI) for grip width, one-repetition maximum (1RM) load, lift distance, peak (PP) and mean (MP) power, distance and time when peak power occurred in the lift, peak (PV) and mean (MV) velocity, peak and mean force, and work for the one-repetition maximum (1RM) traditional and close-grip bench press in resistance-trained men $(\mathrm{n}=21)$.

\begin{tabular}{lcc}
\hline Variable & Traditional Bench Press & Close-Grip Bench Press \\
\hline Grip Width & $0.62 \pm 0.11$ & $0.35 \pm 0.14$ \\
$(\mathrm{~m})$ & $(0.57-0.67)$ & $(0.34-0.36)$ \\
1RM Load & $96.15 \pm 21.82$ & $90.63 \pm 20.35$ \\
$(\mathrm{~kg})$ & $(86.22-106.09)$ & $(81.36-99.89)$ \\
Lift Distance & $0.30 \pm 0.13$ & $0.35 \pm 0.14$ \\
$(\mathrm{~m})$ & $(0.24-0.36)$ & $(0.29-0.41)$ \\
PP & $359.36 \pm 85.54$ & $429.03 \pm 141.96$ \\
$(\mathrm{w})$ & $(320.88-397.85)$ & $(364.41-493.65)$ \\
PP Distance & $0.19 \pm 0.16$ & $0.16 \pm 0.16$ \\
$(\mathrm{~m})$ & $(0.12-0.26)$ & $(0.09-0.23)$ \\
PP Distance & $44.53 \pm 36.49$ & $36.39 \pm 35.27$ \\
$(\%)$ & $(27.92-61.14)$ & $(20.21-58.22)$ \\
Time at PP & $1.68 \pm 1.73$ & $1.18 \pm 1.37$ \\
$(\mathrm{~s})$ & $(0.90-2.47)$ & $(0.55-1.80)$ \\
Time at PP & $51.25 \pm 40.32$ & $40.22 \pm 39.56$ \\
$(\%)$ & $(32.90-69.61)$ & $(22.21-58.22)$ \\
MP & $201.25 \pm 46.00$ & $213.62 \pm 69.19$ \\
$(\mathrm{w})$ & $(180.32-222.20)$ & $(182.13-245.12)$ \\
PV & $0.36 \pm 0.09$ & $0.44 \pm 0.07$ \\
$\left(\mathrm{~m} \cdot \mathrm{s}^{-1}\right)$ & $(0.32-0.40)$ & $(0.41-0.48)$ \\
MV & $0.22 \pm 0.06$ & $0.24 \pm 0.06$ \\
$\left(\mathrm{~m} \cdot \mathrm{s}^{-1}\right)$ & $(0.19-0.24)$ & $(0.21-0.27)$ \\
Peak Force & $1306.09 \pm 304.38$ & $1239.00 \pm 352.65$ \\
$(\mathrm{~N})$ & $(1167.54-1444.64)$ & $(1078.47-1399.52)$ \\
Mean Force & $984.42 \pm 270.85$ & $894.75 \pm 197.52$ \\
$(\mathrm{~N})$ & $(861.13-1107.71)$ & $(804.84-984.66)$ \\
Work & $284.54 \pm 133.11$ & $314.14 \pm 143.34$ \\
$(\mathrm{~J})$ & $(223.95-345.13)$ & $(248.89-379.39)$ \\
\hline & & \\
& & \\
$(\mathrm{m})$ & & \\
\hline
\end{tabular}


Table 2 Correlations between arm span and one-repetition maximum (1RM) load, lift distance, peak and mean power, distance and time when peak power occurred in the lift, peak and mean velocity, peak and mean force, and work for the one-repetition maximum traditional and close-grip bench press in resistance-trained men $(n=21)$.

\begin{tabular}{|c|c|c|c|}
\hline & & $\begin{array}{c}\text { Arm Span and } \\
\text { Traditional Bench Press }\end{array}$ & $\begin{array}{c}\text { Arm Span and } \\
\text { Close-Grip Bench Press }\end{array}$ \\
\hline \multirow[t]{2}{*}{$1 \mathrm{RM}$} & $\mathrm{r}$ & 0.27 & 0.22 \\
\hline & $\mathrm{p}$ & 0.23 & 0.34 \\
\hline \multirow{2}{*}{$\begin{array}{l}\text { Lift Distance } \\
\text { (m) }\end{array}$} & $\mathrm{r}$ & $0.46^{*}$ & 0.42 \\
\hline & $\mathrm{p}$ & 0.04 & 0.06 \\
\hline \multirow{2}{*}{$\begin{array}{l}\text { Peak Power } \\
\text { (w) }\end{array}$} & $\mathrm{r}$ & 0.27 & 0.14 \\
\hline & $\mathrm{p}$ & 0.23 & 0.54 \\
\hline Peak Power & $\mathrm{r}$ & 0.14 & -0.26 \\
\hline Distance (m) & $\mathrm{p}$ & 0.56 & 0.26 \\
\hline Peak Power & $\mathrm{r}$ & 0.09 & -0.31 \\
\hline Distance $(\%)$ & $\mathrm{p}$ & 0.71 & 0.17 \\
\hline \multirow{2}{*}{$\begin{array}{l}\text { Time at Peak Power } \\
\text { (s) }\end{array}$} & $\mathrm{r}$ & -0.08 & -0.32 \\
\hline & $\mathrm{p}$ & 0.73 & 0.15 \\
\hline \multirow{2}{*}{$\begin{array}{l}\text { Time at Peak Power } \\
(\%)\end{array}$} & $\mathrm{r}$ & 0.04 & -0.31 \\
\hline & $\mathrm{p}$ & 0.87 & 0.17 \\
\hline \multirow{2}{*}{$\begin{array}{l}\text { Mean Power } \\
\text { (w) }\end{array}$} & $\mathrm{r}$ & -0.02 & -0.10 \\
\hline & $\mathrm{p}$ & 0.94 & 0.67 \\
\hline \multirow{2}{*}{$\begin{array}{l}\text { Peak Velocity } \\
\left(\mathrm{m} \cdot \mathrm{s}^{-1}\right)\end{array}$} & $\mathrm{r}$ & -0.05 & -0.15 \\
\hline & $\mathrm{p}$ & 0.84 & 0.51 \\
\hline \multirow{2}{*}{$\begin{array}{l}\text { Mean Velocity } \\
\left(\mathrm{m} \cdot \mathrm{s}^{-1}\right)\end{array}$} & $\mathrm{r}$ & -0.24 & -0.32 \\
\hline & $\mathrm{p}$ & 0.29 & 0.16 \\
\hline \multirow{2}{*}{$\begin{array}{l}\text { Peak Force } \\
(\mathrm{N})\end{array}$} & $\mathrm{r}$ & 0.37 & 0.22 \\
\hline & $\mathrm{p}$ & 0.10 & 0.33 \\
\hline \multirow{2}{*}{$\begin{array}{l}\text { Mean Force } \\
\text { (N) }\end{array}$} & $\mathrm{r}$ & 0.20 & 0.23 \\
\hline & $\mathrm{p}$ & 0.38 & 0.32 \\
\hline \multirow{2}{*}{$\begin{array}{l}\text { Work } \\
(\mathrm{J})\end{array}$} & $\mathrm{r}$ & $0.51 *$ & $0.48 *$ \\
\hline & $\mathrm{p}$ & 0.02 & 0.03 \\
\hline
\end{tabular}

* Significant $(\mathrm{p}<0.05)$ relationship between the two variables.

\section{DISCUSSION}

This was the first study to investigate the relationships AS has on the mechanics for the 1RM TBP and CGBP. As hypothesized, the results indicated that AS related to greater work in the TBP and CGBP, and lift distance in the TBP. However, there were no significant relationships between AS and the 1RM load and other mechanical variables of peak and mean power, velocity, and force, and the distance and time where peak power occurred. The results from this study have implications for strength and conditioning coaches with regards to how they may monitor the load associated with TBP and CGBP when performed by individuals that have different AS.

Previous research has indicated that longer leg length related to greater lift distance and work in conventional and hexagonal bar deadlift exercises in resistance-trained men (Lockie et al., in press). Lockie et al. (in press) also found that a longer arm length related to greater work in the conventional deadlift. As the bench press exercise involves moving the bar from the chest to a positon of almost full elbow extension (Algra, 1982; Gomo \& Van Den Tillaar, 2016; Lehman, 
2005), it could be expected that AS would influence the distance the bar needs to travel. The results from this study indicated that this was the case. For both the 1RM TBP and CGBP, a longer AS related to greater work. Coaches should recognize that for individuals that lift equivalent loads in the TBP and CGBP, those with longer arms may end up completing more work. McBride et al. (2009) has detailed the value of using total work to measure the volume and intensity of strength training load. Accordingly, coaches should carefully monitor the work performed during bench press exercises for individuals with longer arms. This is especially if a coach is attempting to equate load across a group of individuals or athletes where AS can vary, such as basketball players (Dawes et al., 2016; Sallet et al., 2005; Teramoto et al., 2018).

With regards to lift distance, there was only a significant relationship between AS and the TBP, which also had a moderate effect. Within the TBP, the participants self-selected their 'strongest position' (Young et al., 2015), which would be done relative to an individual's limb length such that mechanical advantage is optimized (Gomo \& Van Den Tillaar, 2016). This could relate to why AS had a significant relationship with TBP lift distance and not the CGBP lift distance. Nonetheless, although not significant $(\mathrm{p}=0.06)$, the relationship strength between AS and lift distance for the CGBP was still moderate $(r=0.42)$. Furthermore, Lockie et al. (2017a) found no significant differences between the 1RM TBP and CGBP lift distance performed by resistancetrained men and women, while Lockie et al. (2017b) found significant $(\mathrm{r}=0.72, \mathrm{p}<0.01)$ relationships between these two variables for resistance-trained men. Accordingly, it could be expected that AS could have some impact on the lift distance of the CGBP, which in conjunction with the significant relationship with work, could influence how training load is monitored for this exercise in individuals with different AS.

The results indicated that AS had no significant relationships with the 1RM load lifted and the other mechanical variables, including peak and mean power, velocity, and force. There were also no significant relationships between AS and the distance and time when peak power occurred in the TBP and CGBP. Lockie et al. (2017a) documented few significant relationships between arm length and peak and mean power, velocity, and force in deadlift exercises completed by resistance-trained men and women. Specific to the bench press, Wagner et al. (1992) found no significant correlations between arm or forearm length with the load lifted during the bench press performed with grip widths of $90-270 \%$ BAD by strength-trained men. Given the importance of neuromuscular control for the generation of power, velocity, and force in bench press exercises (Stastny et al., 2017; Stock, Beck, Defreitas, \& Dillon, 2010), this provides some evidence as to why AS by itself may not exhibit significant relationships with these other key mechanical variables. More importantly, what this data suggests is that greater or lesser AS may not effect on the generation of power, velocity, and force in the TBP and CGBP, and the potential adaptations that could result from using these exercises in training. This is useful information, as the TBP commonly features in resistance training programs (Baker, 2001; Coutts, Murphy, \& Dascombe, 2004; Crewther, Heke, \& Keogh, 2013; Drinkwater et al., 2005; Marston et al., 2017), and the CGBP could be used to specifically target sport-specific actions (Lockie et al., 2017a; Lockie et al., 2017b; Lockie \& Moreno, 2017). Regardless of an individual's AS, they could use the TBP and CGBP to potentially enhance upper-body power, velocity, and force and during pushing movements.

There are certain study limitations that should be acknowledged. This study only utilized 1RM loads for both the TBP and CGBP. Potentially, relationships with AS could be different if submaximal loads were used for these exercises. This study utilized a linear position transducer to measure lifting mechanics, in order to ensure the data would have practical value to coaches (Drinkwater et al., 2007; Harris et al., 2010; Lockie et al., 2017a; Lockie et al., 2018; Lockie et al., in press). However, the use of motion capture to measure lifting mechanics and the influence of AS could provide different results. Although the participants in this study were resistance-trained and similar to populations analyzed in the literature (Lockie et al., 2017a; Lockie et al., 2017b), they may not necessarily be considered 'strong'. The 1RM TBP for the participants in this study was $96.15 \pm 21.82 \mathrm{~kg}$ (relative strength $=1.17 \mathrm{~kg}$ per $\mathrm{kg}$ body mass); powerlifters have been found to 
have a $1 \mathrm{RM}$ TBP of $131.5 \pm 22.9 \mathrm{~kg}$, with equates to a relative strength measure of $1.70 \mathrm{~kg}$ per $\mathrm{kg}$ body mass (Gomo \& Van Den Tillaar, 2016). Similar to what has been suggested by Lockie et al. (2017b), future research could investigate the effects AS may have on TBP and CGBP lifting mechanics in stronger populations, including powerlifters, and American football and rugby players. Furthermore, future research could also incorporate athletes who are taller (e.g. basketball and volleyball players), as they will likely have a longer AS. For example, Division II collegiate male basketball players had an arm span of $2.00 \pm 0.10 \mathrm{~m}$ (Dawes et al., 2016), which is $10 \%$ greater than that measured from the participants in this study $(1.81 \pm 0.08 \mathrm{~m})$. A longer AS may impact TBP and CGBP lifting mechanics to a greater extent.

\section{CONCLUSION}

In conclusion, the results from this study demonstrated that a longer AS related to greater lift distance and work in the TBP. For the CGBP, a longer AS related to more work performed. Resistance-trained men with a longer AS may move the bar further and perform more work in the 1 RM TBP and CGBP. This could influence how coaches measure training volume and intensity if load is to be equated across a group, especially if there are individuals with longer AS. AS did not exhibit significant relationships with other important mechanical variables in the 1RM TBP and CGBP, including peak and mean power, velocity, and force. Accordingly, greater or lesser AS may not have an effect on the generation of power, velocity, and force in the TBP and CGBP, and the potential adaptations that could result from training with each exercise.

Acknowledgments. We would like to acknowledge our participants for their contribution to this study. Thanks also Victoria Amran, Alyssa Stage, Tricia Liu, John Stokes, Samantha BirminghamBabauta, Dominic Giuliano, Adrina Lazar, Ibett Torne, Megan Beiley, Jillian Hurley, Fabrice Risso, DeShaun Davis, Michael Silva, and Karisha Mae Rosure for assisting with data collection. This research project received no external financial assistance. None of the authors have any conflict of interest.

\section{REFERENCES}

Algra, B. (1982). In-depth analysis of the bench press. National Strength and Conditioning Association Journal, 4 (6-7; 10-11; 70-72).

Baker, D. (2001). The effects of an in-season of concurrent training on the maintenance of maximal strength and power in professional and college-aged rugby league football players. Journal of Strength and Conditioning Research, 15, 172-177.

Barnett, C., Kippers, V., \& Turner, P. (1995). Effects of variations of the bench press exercise on the EMG activity of five shoulder muscles. Journal of Strength and Conditioning Research, 9, 222-227.

Clemons, J.M., \& Aaron, C. (1997). Effect of grip width on the myoelectric activity of the prime movers in the bench press. Journal of Strength and Conditioning Research, 11, 82-87.

Coutts, A.J., Murphy, A.J., \& Dascombe, B.J. (2004). Effect of direct supervision of a strength coach on measures of muscular strength and power in young rugby league players. Journal of Strength and Conditioning Research, 18, 316-323.

Crewther, B.T., Heke, T.L., \& Keogh, J.W. (2013). The effects of a resistance-training program on strength, body composition and baseline hormones in male athletes training concurrently for rugby union 7's. Journal of Sports Medicine and Physical Fitness, 53, 34-41.

Cronin, J. B., \& Owen, G. J. (2004). Upper-body strength and power assessment in women using a chest pass. Journal of Strength and Conditioning Research, 18, 401-404.

Dawes, J., Marshall, M., \& Spiteri, T. (2016). Relationship between pre-season testing performance and playing time among NCAA DII basketball players. Sports and Exercise Medicine Open Journal, 2, 47-54. 
Delextrat, A., \& Cohen, D. (2009). Strength, power, speed, and agility of women basketball players according to playing position. Journal of Strength and Conditioning Research, 23, 1974-1981.

Drinkwater, E.J., Galna, B., McKenna, M.J., Hunt, P. H., \& Pyne, D.B. (2007). Validation of an optical encoder during free weight resistance movements and analysis of bench press sticking point power during fatigue. Journal of Strength and Conditioning Research, 21, 510-517.

Drinkwater, E. J., Lawton, T. W., Lindsell, R. P., Pyne, D. B., Hunt, P. H., \& McKenna, M. J. (2005). Training leading to repetition failure enhances bench press strength gains in elite junior athletes. Journal of Strength and Conditioning Research, 19, 382-388.

Drinkwater, E.J., Moore, N.R., \& Bird, S.P. (2012). Effects of changing from full range of motion to partial range of motion on squat kinetics. Journal of Strength and Conditioning Research, 26, 890-896.

Dumith, S. C., Ramires, V.V., Souza, M.A., Moraes, D.S., Petry, F.G., Oliveira, E.S., Ramires, S.V., \& Hallal, P.C. (2010). Overweight/obesity and physical fitness among children and adolescents. Journal of Physical Activity and Health, 7, 641-648.

Faul, F., Erdfelder, E., Lang, A.G., \& Buchner, A. (2007). G*Power 3: a flexible statistical power analysis program for the social, behavioral, and biomedical sciences. Behavior Research Methods, 39, 175-191.

Fry, A.C., \& Kraemer, W.J. (1997). Resistance exercise overtraining and overreaching. Neuroendocrine responses. Sports Medicine, 23, 106-129.

Gomo, O., \& Van Den Tillaar, R. (2016). The effects of grip width on sticking region in bench press. Journal of Sports Sciences, 34, 232-238.

Harris, N.K., Cronin, J., Taylor, K.L., Boris, J., \& Sheppard, J. (2010). Understanding position transducer technology for strength and conditioning practitioners. Strength and Conditioning Journal, 32, 66-79.

Hopkins, W.G. (2002). A scale of magnitude for effect statistics. Retrieved January 8, 2017, from the World Wide Web: www.sportsci.org/resource/stats/index.html.

Hopkins, W.G. (2004). How to interpret changes in an athletic performance test. Sportscience, 8, 1-7.

Lehman, G.J. (2005). The influence of grip width and forearm pronation/supination on upper-body myoelectric activity during the flat bench press. Journal of Strength and Conditioning Research, 19, 587-591.

Lockie, R.G., Callaghan, S.J., Moreno, M.R., Risso, F.G., Liu, T.M., Stage, A.A., Birmingham-Babauta, S.A., Stokes, J.J., Giuliano, D.V., Lazar, A., Davis, D.L., \& Orjalo, A.J. (2017a). An investigation of the mechanics and sticking region of a one-repetition maximum close-grip bench press versus the traditional bench press. Sports, 5 (3), 46.

Lockie, R.G., Callaghan, S.J., Moreno, M.R., Risso, F.G., Liu, T.M., Stage, A.A., Birmingham-Babauta, S.A., Stokes, J.J., Giuliano, D.V., Lazar, A., Davis, D.L., \& Orjalo, A.J. (2017b). Relationships between mechanical variables in the traditional and close-grip bench press. Journal of Human Kinetics, 60, 19-28.

Lockie, R.G., \& Moreno, M.R. (2017). The close-grip bench press. Strength and Conditioning Journal, 39, 30-35.

Lockie, R.G., Moreno, M.R., Lazar, A., Risso, F.G., Tomita, T.M., Stage, A.A., Birmingham-Babauta, S.A. Torne, I.A., Stokes, J.J., Giuliano, D.V., Davis, D.L., Orjalo, A.J., \& Callaghan, S.J. (2018). The 1repetition maximum mechanics of a high-handle hexagonal bar deadlift compared to a conventional deadlift as measured by a linear position transducer. Journal of Strength and Conditioning Research, 32, 150-161.

Lockie, R.G., Moreno, M.R., Orjalo, A.J., Lazar, A., Liu, T.M., Stage, A.A., Birmingham-Babauta, S.A., Stokes, J.J., Giuliano, D.V., Risso, F.G., Davis, D.L., \& Callaghan, S.J. (in press). The relationships between height, arm length, and leg length on the mechanics of the conventional and high-handle hexagonal bar deadlift. Journal of Strength and Conditioning Research, doi:10.1519/jsc.0000000000002256.

Marston, K.J., Peiffer, J.J., Newton, M.J., \& Scott, B.R. (2017). A comparison of traditional and novel metrics to quantify resistance training. Scientific Reports, 7, 5606.

McBride, J.M., McCaulley, G.O., Cormie, P., Nuzzo, J.L., Cavill, M.J., \& Triplett, N.T. (2009). Comparison of methods to quantify volume during resistance exercise. Journal of Strength and Conditioning Research, 23, 106-110.

Sallet, P., Perrier, D., Ferret, J. M., Vitelli, V., \& Baverel, G. (2005). Physiological differences in professional basketball players as a function of playing position and level of play. Journal of Sports Medicine and Physical Fitness, 45, 291-294.

Smilios, I., Sotiropoulos, K., Christou, M., Douda, H., Spaias, A., \& Tokmakidis, S.P. (2013). Maximum power training load determination and its effects on load-power relationship, maximum strength, and vertical jump performance. Journal of Strength and Conditioning Research, 27, 1223-1233.

Stastny, P., Gołaś, A., Blazek, D., Maszczyk, A., Wilk, M., Pietraszewski, P., Petr, M., Uhlir, P., \& Zając, A. (2017). A systematic review of surface electromyography analyses of the bench press movement task PLOS ONE, 12, e0171632. 
Stock, M.S., Beck, T.W., Defreitas, J. M., \& Dillon, M.A. (2010). Relationships among peak power output, peak bar velocity, and mechanomyographic amplitude during the free-weight bench press exercise. Journal of Sports Sciences, 28, 1309-1317.

Stokes, J.V., Luiselli, J.K., Reed, D.D., \& Fleming, R.K. (2010). Behavioral coaching to improve offensive line pass-blocking skills of high school football athletes. Journal of Applied Behavior Analysis, 43, 463-472.

Teramoto, M., Cross, C.L., Rieger, R.H., Maak, T.G., \& Willick, S.E. (2018). Predictive validity of National Basketball Association draft combine on future performance. Journal of Strength and Conditioning Research, 32, 396-408.

Wagner, L.L., Evans, S.A., Weir, J. P., Housh, T.J., \& Johnson, G.O. (1992). The effect of grip width on bench press performance. International Journal of Sport Biomechanics, 8, 1-10.

Wheeler, K., \& Sayers, M. (2009). Contact skills predicting tackle-breaks in rugby union. International Journal of Sports Science and Coaching, 4, 535-544.

Wheeler, K.W., \& Sayers, M.G.L. (2011). Rugby union contact skills alter evasive agility performance during attacking ball carries. International Journal of Sports Science and Coaching, 6, 419-432.

Young, K.P., Haff, G.G., Newton, R.U., Gabbett, T.J., \& Sheppard, J.M. (2015). Assessment and monitoring of ballistic and maximal upper-body strength qualities in athletes. International Journal of Sports Physiology and Performance, 10, 232-237.

\section{RELACIJE IZMEĐU RASPONA RUKU I MEHANIKE JEDNOPONAVLJAJUĆEG MAKSIMUMA TRADICIONALNOG I USKOHVATNOG POTISKA SA KLUPE}

Tradicionalni benč pres (TBP), izveden sa širokim hvatom koji daje maksimalnu snagu, popularna je vežba za razvoj gornjeg dela tela. Uskohvatni benč pres (CGBP) je varijanta TBP često korišćena da naglasi triceps brahi u odnosu na glavne pokretače kao što je pectoralis major. Raspon ruke pojedinca (AS, rastojanje između srednjih prstiju ruke dok su ruke ispružene) može uticati na mehaniku svakog vežbanja, što se može pogoršati promenom hvata. Ovo istraživanje ispitivalo je odnose između AS i TBP i CGBP mehanike kod muškaraca koju su podvrgnuti treningu sa optrećenjem. Dvadeset jedan ispitanik je izvršio maksimum sa jednim ponavljanjem (1RM) TBP $i$ CGBP. TBP je izveden sa željenim hvatom (mereno u odnosu na biakromijalno rastojanje [BAD]), $i$ CGBP sa širinom hvata od 95\% BAD-a. Izmeren je linearni položaj transduktora: rastojanje podizanja; maksimalna $i$ srednja snaga, brzina $i$ sila; razdaljinu $i$ vreme kada se pojavila maksimalna snaga i rad. Pearsonove korelacije $(r ; p<0.05)$ izračunale su odnose između mehanike AS i TBP $i$ CGBP. Postojale su značajne pozitivne veze između rastojanja podizanja $A S i T B P$ i rada $(r=0,46 i 0,51$, respektivno). Za CGBP, postojala je značajna pozitivna veza između AS i rada $(r=0,48)$. Nije bilo drugih značajnih korelacija između AS $i$ mehanike podizanja. Muškarci podvrgnuti treningu sa opterećenjem sa dužim AS mogu dalje pomeriti šipku i proizvesti veći rad kod IRM TBP i CGBP. Ovo bi moglo uticati na to kako treneri mere obim treninga $i$ intenzitet za pojedince sa različitim $A S$.

Ključne reči: dužina ruke, rastojanje podizanja, linearni položaj transduktora, snaga godnjeg dela tela 